Note

\title{
Characterization of Bacillus Subtilis Isolated from Asian Fermented Foods
}

\author{
Panthitra Phromraksa ${ }^{1}$, Hiroko Nagano ${ }^{2 *}$, Yoshihiro Kanamaru ${ }^{3}$, Hidehiko Izumi ${ }^{4}$, Chikako Yamada ${ }^{4}$ and \\ Chirasak KHAMBOONRUANG ${ }^{5}$ \\ ${ }^{1}$ The United Graduate School of Agricultural Science, Gifu University, Gifu 501-1193, Japan \\ ${ }^{2}$ Faculty of Education, Gifu University, Gifu 501-1193, Japan \\ ${ }^{3}$ Department of Applied Life Science, Faculty of Applied Biological Sciences, Gifu University, Gifu 501-1193, Japan \\ ${ }^{4}$ School of Nutritional Sciences, Nagoya University of Arts and Sciences, Nissin, Aichi 470-0196, Japan \\ ${ }^{5}$ Chiang Mai University, Chiang Mai 50200, Thailand
}

Received March 16, 2009; Accepted July 27, 2009

Eleven Bacillus subtilis strains capable of producing protease were isolated from fermented foods and characterized. B. subtilis DB and SR were selected for digesting rice proteins. It was found that they could reduce rice allergenicity by hydrolyzing allergenic fragments detected by immunoblotting. Moreover, the fact that $B$. subtilis SR could also digest rice proteins resulted in the increase of glutamic acid, which is the important amino acid for $\gamma$-aminobutyric acid (GABA) production. Therefore, $B$. subtilis SR has the potential for application in the production of hypoallergenic fermented rice-noodle with high nutrient availability.

Keywords: Bacillus subtilis, proteolytic bacteria, protease, $\boldsymbol{\gamma}$-aminobutyric acid (GABA), fermented food

\section{Introduction}

Fermented foods have traditionally been produced and consumed for centuries. Food characteristics are unique depending on climate and location. Raw materials commonly come from local agricultural products such as cereals, legumes, vegetables, milk, fish, meat, and so on.

Bacillus strains have been involved in food fermentation processes. They are able to produce high potential proteases, and their main activity during fermentation is enzymatic proteolysis (Ouoba et al., 2004). Most Bacillus strains are not harmful to humans (Leonel Ochoa-Solano and Olmos-Soto, 2006). Bacillus proteases are very efficient in breaking down proteins into smaller units. Moreover, Bacillus fermentation can provide products with high nutrient availability (Kiers et al., 2000). Therefore, the knowledge of how to exploit their potential should be disseminated.

Our previous researches have focused on Bacillus strains from fermented cereal foods. In Thailand, a variety of microorganisms, including aerobic bacteria, lactic acid bacteria, fungi and yeast, have been found in fermented rice-noodles

*To whom correspondence should be addressed.

E-mail: nagano@gifu-u.ac.jp
(Kha Nhom Jeen). We recently found numerous aerobic bacteria in soaked rice and rice blocks from production processing of fermented rice-noodles (Kobayashi et al., 2007). B. subtilis, isolated from the soaked rice, showed interesting properties that have the potential to reduce allergenicity of wheat allergen (gliadin) (Phromraksa et al., 2008). In Myanmar, Ikeda et al. (2005) reported that B. subtilis, isolated from soaked rice from fermented rice-noodle (Mohinger) processing, showed high proteolytic activities towards the protein substrates, azocasein and azocollagen, and could digest allergenic rice protein.

The present study aimed to clarify the proteolytic potential of Bacillus strains from various Asian fermented foods. Proteolytic bacteria were isolated and a phylogenetic tree was constructed. Because all isolated bacteria were of the same species, B. subtilis, in order to examine whether all bacteria also had the same level of proteolytic activity, characterization of bacteria using synthetic substrates was performed. In addition, to investigate the possibility of utilizing the bacteria in rice fermentation, the effects of selected bacteria on rice proteins were examined. 


\section{Materials and Methods}

Food samples and bacteria Five kinds of fermented food samples were collected from 5 Asian countries: Thailand, Japan, Mongolia, Laos, and Vietnam. These samples included 1 sample of fermented soybean seeds collected from Thailand in 2003, 3 samples of wheat flour dough (each collected from Thailand in 2003, Japan in 1992 and Mongolia in 1995), 1 sample of soaked rice used for fermented ricenoodle (Kha Nhom Jeen) processing collected from Thailand in 2003, 1 sample of Thai fermented soybean paste collected in 2003, and 2 samples of fish sauce (each collected from Laos in 1995 and Vietnam in 2000).

The samples were suspended in sterilized distilled water, spread on nutrient agar slants (containing $0.5 \%$ glucose $(\mathrm{Na}-$ calai Tesque, Japan)) and incubated at room temperature. All bacteria were maintained before screening on nutrient agar slants (containing $0.5 \%$ glucose) at $4^{\circ} \mathrm{C}$.

Media The media for screening proteolytic bacteria and enzyme production were prepared according to the method described by Phromraksa et al. (2008).

Gelatin stab medium contained $1.8 \%$ nutrient medium (Eiken Chemical, Japan) and 17\% gelatin (Nacalai Tesque). The medium was sterilized at $121^{\circ} \mathrm{C}$ for $15 \mathrm{~min}$ and kept at $4^{\circ} \mathrm{C}$ until use.

Screening of bacteria After bacteria were cultured overnight on nutrient agar slants (containing $0.5 \%$ glucose), each bacterium was cultured on a nutrient agar slant (containing $10 \% \mathrm{NaCl}$ (Wako Pure Chemical Industries Ltd., Japan)) at $37^{\circ} \mathrm{C}$ for $24 \mathrm{~h}$. Uninoculated identical medium was used as a control.
Enzyme activities towards gelatin were examined in all bacteria cultured on nutrient agar. Each bacterium was stabbed through the center of gelatin stab medium and cultured at $37^{\circ} \mathrm{C}$ for $72 \mathrm{~h}$. Subsequently, all culture tubes were kept at $4^{\circ} \mathrm{C}$ overnight. Liquefaction of the medium is an indicator of bacterial enzyme activity. Uninoculated identical medium was used as a control.

Phylogenetic analysis Eleven B. subtilis strains were isolated and identified by $16 \mathrm{~S}$ rDNA sequencing in our previous study (Nagano and To, 2000; Tran and Nagano, 2002; Liu and Nagano, 2008; Phromraksa et al., 2008). The $16 \mathrm{~S}$ rDNA sequences of bacteria were deposited in the DDBJ database under the accession numbers shown in Table 1.

The multiple alignments of all sequences determined were performed with the MEGA software version 4.0.2 (Tamura et al., 2007). The distance matrices for the aligned sequences were calculated by the two-parameter method of Kimura (1980). A phylogenetic tree was constructed by the neighbor-joining method (Saitou and Nei, 1987).

Reference strains used for the homology study were type strains of B. subtilis DSM10 (AJ276351), B. licheniformis (X68416), and B. pumilus DSMZ27 (AY456263).

Preparation of extracellular enzyme Each bacterium was refreshed by aerobic incubation overnight in an enzyme production medium at $37^{\circ} \mathrm{C}$. Using this culture as a starter, the bacterium could be aerobically grown in the same medium at $37^{\circ} \mathrm{C}$ for $48 \mathrm{~h}$. The broth was centrifuged at 10,000 rpm for $5 \mathrm{~min}$. The supernatant was used as bacterial extracellular enzyme.

Preparation of bacterial enzyme Ammonium sulfate

Table 1. Isolated B. subtilis strains from Asian fermented foods.

\begin{tabular}{|c|c|c|c|c|c|}
\hline Country & Source & Strain & Accession no. & Salt tolerance & Galatinase activity \\
\hline \multirow[t]{7}{*}{ Thailand } & Soybean seeds & B. subtilis SB3 & AB440267 & + & + \\
\hline & & B. subtilis SB4 & AB440266 & + & + \\
\hline & & B. subtilis SB5 & AB440268 & + & + \\
\hline & Wheat flour dough & B. subtilis DB & AB440269 & + & + \\
\hline & Rice & B. subtilis $\mathrm{SR}$ & AB440270 & + & + \\
\hline & Soybean paste & B. subtilis SP1 & AB440271 & + & + \\
\hline & & B. subtilis SP2 & AB440272 & + & + \\
\hline Japan & Wheat flour dough & B. subtilis JK & AB509381 & + & + \\
\hline Mongolia & & B. subtilis M2-4 & AB379850 & + & + \\
\hline Laos & Fish sauce & B. subtilis $\mathrm{FS}-2$ & AB447487 & + & + \\
\hline Vietnam & & B. subtilis $\mathrm{CN}-2$ & AB383135 & + & + \\
\hline
\end{tabular}


(Wako Pure Chemical Industries Ltd.) was slowly added to the extracellular enzyme solution until $80 \%$ saturation was reached. The solution was gently stirred and kept at $4{ }^{\circ} \mathrm{C}$ overnight in the refrigerator. The precipitate was separated by centrifugation at 10,000 rpm for $20 \mathrm{~min}$. The precipitated protein was dissolved in $0.1 \mathrm{M}$ potassium phosphate buffer $(\mathrm{pH} 7)$ and then dialyzed against distilled water at $4^{\circ} \mathrm{C}$ for 48 $\mathrm{h}$. The product was used as bacterial enzyme.

Enzyme activity using synthetic substrate Enzyme activities were measured spectrophotometrically using the synthetic substrates, Suc-AAPF-pNA (Suc-Ala-Ala-ProPhe-pNA) and Bz-FVR-pNA (Bz-Phe-Val-Arg-pNA). The $600-\mu \mathrm{L}$ mixture, containing $2.63 \mathrm{mg}$ protein $/ \mathrm{mL}$ of bacterial enzyme and $20 \mathrm{mM}$ Tris- $\mathrm{HCl}$ buffer ( $\mathrm{pH} 8$ ), was pre-incubated at $37^{\circ} \mathrm{C}$ for $2 \mathrm{~min}$. Then, $200 \mu \mathrm{L}$ of $0.5 \mathrm{mM}$ Suc-AAPFpNA (Sigma-Aldrich, USA) or $0.25 \mathrm{mM} \mathrm{Bz-FVR-pNA}$ (Sigma-Aldrich) was added to the mixture and incubated at $37^{\circ} \mathrm{C}$ for $5 \mathrm{~min}$. The amount of $p$-nitroanilide liberated was determined from the absorption at $405 \mathrm{~nm}$. The same mixture, without substrate, was used as a control. Results are expressed as $p$-nitroanilide released calculated by linear regression analysis from the standard curve prepared with a known concentration of $p$-nitroanilide. One unit of activity was defined as $p$-nitroanilide released per amount of enzyme per minute.

The FALGPA (N-(3-[2-Furyl]acryloyl)-Leu- Gly-ProAla) assay was performed as originally described by Van Wart and Steinbrink (1981) with the following modifications. The reaction mixture was composed of $800 \mu \mathrm{L}$ of $0.1 \mathrm{mM}$ FALGPA (Sigma-Aldrich) in $50 \mathrm{mM}$ tricine (BIO-RAD Laboratories, USA), $10 \mathrm{mM} \mathrm{CaCl}_{2}$ (Nacalai Tesque), $400 \mathrm{mM}$ $\mathrm{NaCl}, \mathrm{pH} 7.5$, and $3.95 \mathrm{mg}$ protein $/ \mathrm{mL}$ of bacterial enzyme. The mixtures were incubated at $22^{\circ} \mathrm{C}$ for $24 \mathrm{~h}$. Hydrolysis of FALGPA was determined by measuring the decrease in absorbance at $324 \mathrm{~nm}$. The same mixture, without FALGPA, was use as a control. One unit of activity was defined as the decrease of 0.1 unit of absorbance at $324 \mathrm{~nm}$ in $24 \mathrm{~h}$ under assay conditions.

Preparation of rice proteins Rice proteins were prepared according to the method described by Li et al. (2007) with slight modifications. Rice seeds were ground to pass through a $250-\mu \mathrm{m}$ mesh screen. Protein isolates were prepared from rice flour by extraction with $0.085 \mathrm{M} \mathrm{NaOH}$ (Nacalai Tesque) (1:12 w/v flour:water ratio) for $4 \mathrm{~h}$ at room temperature. The suspension thus obtained was centrifuged at 3,000 $\mathrm{g}$ for $20 \mathrm{~min}$. The supernatant was removed and adjusted to $\mathrm{pH} 5.5$ with $2 \mathrm{~N} \mathrm{HCl}$ (Nacalai Tesque). The protein precipitate formed was centrifuged at 3,000 $\mathrm{g}$ for $20 \mathrm{~min}$, washed twice with distilled water, and then lyophilized. The products were used as rice proteins.
Digestion of rice proteins Each mixture was composed of $500 \mu \mathrm{L}$ of $3 \%$ rice protein solution and $2.55 \mathrm{mg} / \mathrm{mL}$ of extracellular enzyme of each of 2 bacteria (B. subtilis DB and SR). The enzyme was added separately. These mixtures were incubated at $37^{\circ} \mathrm{C}$ for 0 and $24 \mathrm{~h}$, respectively, and the reaction was terminated by boiling for $5 \mathrm{~min}$. The mixtures were used as digested samples. The digested fragments were detected by $15 \%$ SDS-PAGE.

Amino acid composition analysis of digested samples was performed by HPLC analysis. The HPLC system used was a Hitachi ELITE LaChrom (Hitachi High-Technologies Corporation, Tokyo, Japan), equipped with an L-2130 pump, an L-2200 autosampler, an L-2350 column oven and an L-2485 FL detector. The column used was a NIN/OPA 4.0 $\mathrm{mm} \mathrm{I.D} \mathrm{x} 150 \mathrm{~mm} \mathrm{~L}$ (TR3-2004), operating at $55^{\circ} \mathrm{C}$ and with a flow rate of $0.4 \mathrm{~mL} / \mathrm{min}$. The injected volume was optimized to $20 \mu \mathrm{L}$.

SDS-PAGE and immunoblotting Samples were analyzed using SDS-PAGE (Laemmli 1970). Immunoblotting was performed according to Phromraksa et al. (2008) with slight modifications. Proteins on the gel were electrotransferred onto a PVDF membrane (ATTO, Japan) and then blocked overnight at $4^{\circ} \mathrm{C}$ with $1 \%$ skim milk (Difco, USA) in TBS-T (Tris-buffered saline, $\mathrm{pH}$ 7.4, containing $0.1 \%$ Tween-20). The membrane was incubated for $1 \mathrm{~h}$ at $37^{\circ} \mathrm{C}$ in TBS-T containing a monoclonal antibody specific for $14-16-\mathrm{kDa}$ rice allergens (diluted 1:2000) with gentle shaking. After the membrane was washed with TBS-T, TBS-T containing polyclonal rabbit anti-human IgE/HRP (diluted 1:5000) (Dako Cytomation, Denmark) was added and incubated for $1 \mathrm{~h}$ at $37^{\circ} \mathrm{C}$ with gentle shaking. The membrane was then washed with TBS-T. The reacted protein bands were detected by a light-emitting non-radioactive method (Amersham Biosciences UK Ltd., UK).

\section{Results and Discussion}

Phylogeny of isolated B. subtilis Various bacteria have been found in fermented foods, including Bacillus spp. Protein food fermentation is usually based on alkaline fermentation by Bacillus spp., in which B. subtilis is the predominant bacteria responsible. Other species of Bacillus, such as $B$. licheniformis, B. pumilus, B. cereus, B. megaterium, B. badius, $B$. sphaericus and B. fusiformis, are also commonly found in fermented foods (Ouoba et al., 2008). Chantawannakul et al. (2002) and Inatsu et al. (2006) reported that the highly proteolytic bacteria involved in the Thai traditional fermented soybean, Thua Nao, were B. subtilis.

Isolated proteolytic bacteria in the present study are shown in Table 1. These bacteria were pre-screened for salt tolerance and enzyme activity towards gelatin. Eleven bac- 


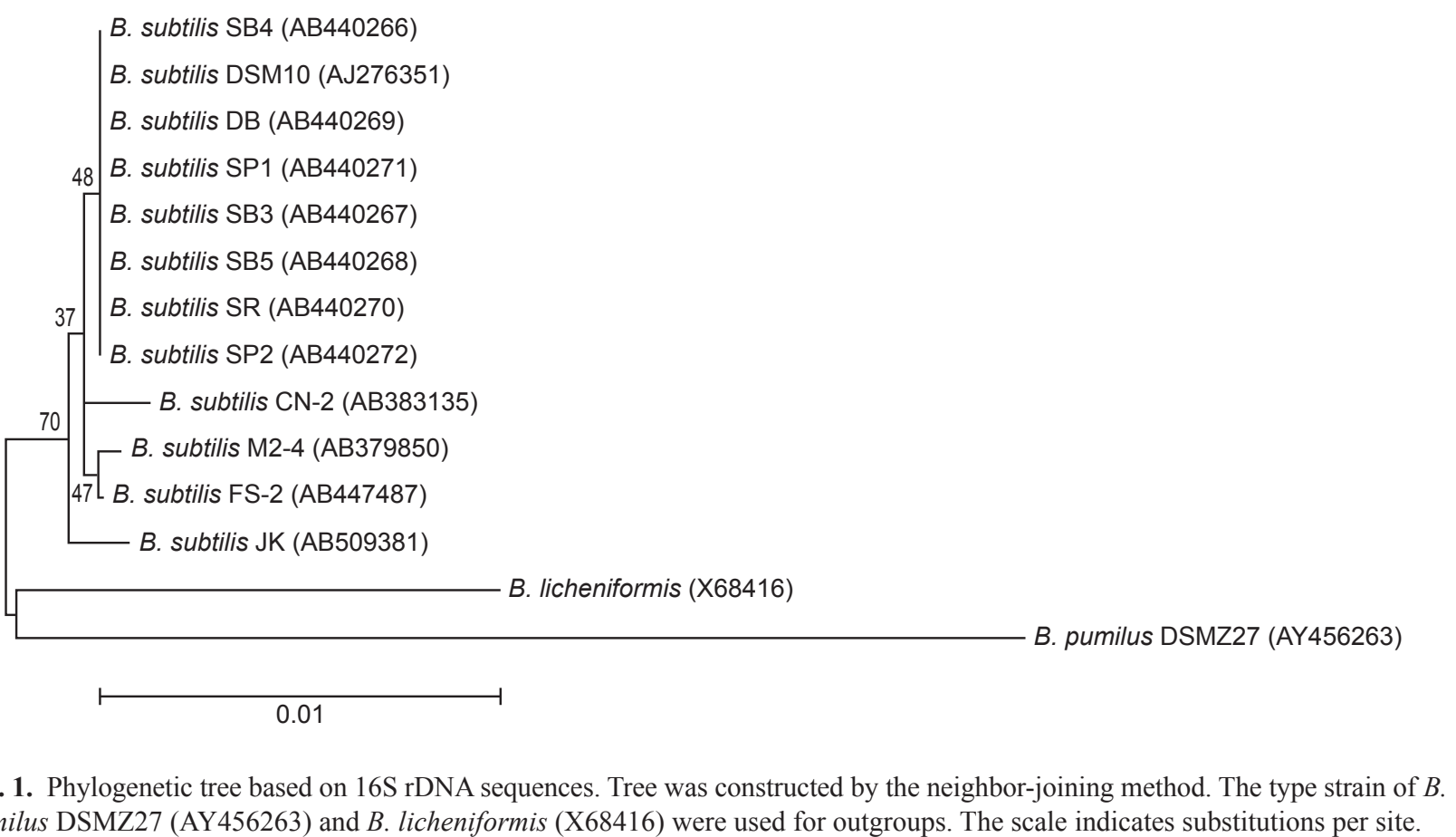

pumilus DSMZ27 (AY456263) and B. licheniformis (X68416) were used for outgroups. The scale indicates substitutions per site.

teria were able to grow on the $10 \% \mathrm{NaCl}$ medium, and they were also positive for gelatin liquefaction. The results indicate that these bacteria have the ability to grow under high salt concentration conditions, and have proteolytic activity towards gelatin substances.

A phylogenetic tree, based on the 16S rDNA sequences of 11 isolated bacteria and 3 representative reference strains, is shown in Fig. 1. The isolated bacteria were clearly separated from the reference strains B. licheniformis (X68416) and $B$. pumilus DSMZ27 (AY456263), but were grouped together with the reference strains of $B$. subtilis DSM10 (AJ276351). These Bacillus isolates were shown to be closely related, by means of phylogenetic analysis. In order to clarify their characteristics, their enzyme activities were assayed.

Enzyme activity using synthetic substrates In our previous research, numerous bacteria were pre-screened by medium plates containing insoluble collagen. Many proteolytic bacteria were isolated and characterized with hydrophilic and hydrophobic protein substrates, azocasein and insoluble collagen. It was found that their enzyme activities varied among these substrates (data not shown). The bacterial enzymes were then characterized using synthetic substrates.

Bacterial enzymes had various enzyme activities on synthetic substrates (Figs. 2, 3, and 4). Figure 2 shows that almost all bacteria, except $B$. subtilis SB4, FS-2 and CN-2, have high enzyme activities towards Suc-AAPF-pNA, a synthetic substrate specific for subtilisin and chymotrypsin (Peng et al., 2003). Moreover, these levels of enzyme activities were the same level as the reported enzyme activity of
B. subtilis DC33, a highly proteolytic bacteria isolated from Chinese fermented soybean (Wang et al., 2006).

Bz-FVR-pNA is a synthetic substrate specific for trypsin (Ahn et al., 2003). The bacterial enzyme activities varied among them, even with the bacteria belong to the same species, B. subtilis. Moreover, B. subtilis JK and $\mathrm{CN}-2$ were unable to degrade this substrate (Fig. 3).

FALGPA is a good collagenase-specific substrate that can not be hydrolyzed by other enzymes such as chymotrypsin, trypsin, thermolysin, elastase, papain or carboxypeptidase A (Van Wart and Steinbrink, 1981; Jackson et al., 1995). Five bacteria (B. subtilis SB5, DB, M2-4, FS-2, and CN-2) exhibited high levels of enzyme activity towards this substrate (Fig. $4)$.

B. subtilis DB and M2-4 were found to exhibit high enzyme activities towards these 3 substrates. $B$. subtilis $\mathrm{DB}$ and SR were previously reported to have the ability to reduce the allergenicity of wheat allergens, such as gliadin; while B. subtilis DB was able to reduce the allergenicity of milk allergens, such as $\beta$-lactoglobulin (Phromraksa et al., 2008). Moreover, the results from the present study were expected to support the development of fermented rice-noodle. $B$. subtilis DB and SR were therefore subjected to the next experiment involving digestion of rice proteins.

Digestion of rice proteins The digestion of rice proteins by each enzyme of B. subtilis DB and SR is shown in Fig. $5 \mathrm{~A}$. After incubating with bacterial extracellular enzyme for $24 \mathrm{~h}$, followed by detection with $15 \%$ SDS-PAGE, the enzyme of B. subtilis DB (lane 4) and SR (lane 6) were found 


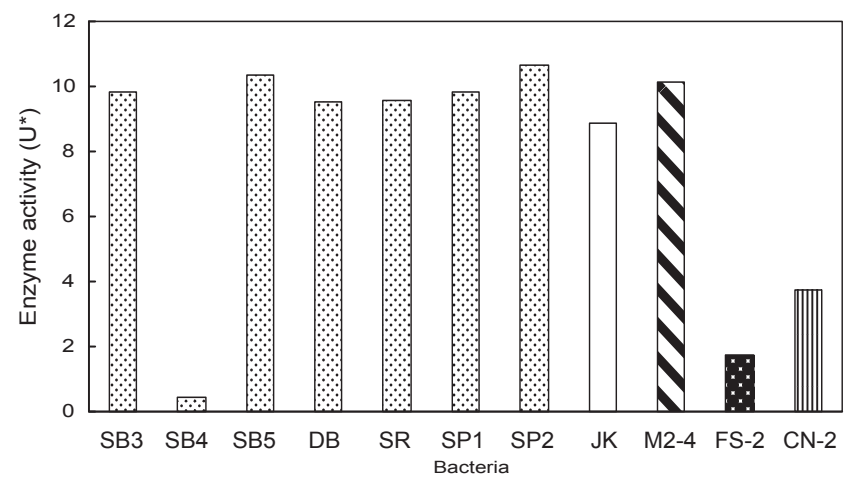

Fig. 2. Amidolytic activity of bacterial enzymes towards Suc-AAPF-pNA.

SB3, B. subtilis SB3; SB4, B. subtilis SB4;SB5, B. subtilis SB5; $\mathrm{DB}$, B. subtilis $\mathrm{DB}$; SR, B. subtilis $\mathrm{SR}$; SP1, B. subtilis $\mathrm{SP} 1$, SP2, B. subtilis SP2; JK, B. subtilis JK; M2-4, B. subtilis M2-4; FS-2, B. subtilis $\mathrm{FS}-2$; $\mathrm{CN}-2$, B. subtilis $\mathrm{CN}-2$.

* One unit (U) of activity was defined as $\mu$ mol $p$-nitroanilide released per gram of enzyme per minute.

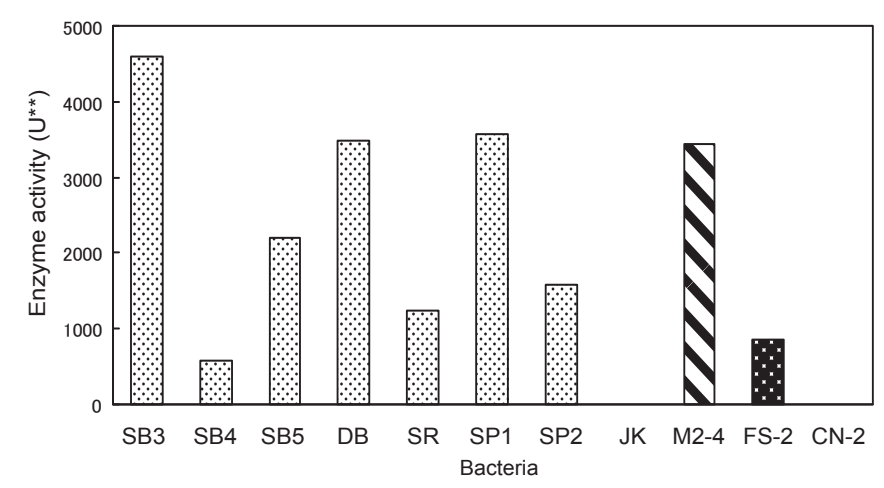

Fig. 3. Amidolytic activity of bacterial enzymes towards Bz-FVR-pNA.

Bacteria used in Fig. 3. are the same as in Fig. 2.

** One unit $(\mathrm{U})$ of activity was defined as mol $p$-nitroanilide released per gram of enzyme per minute.

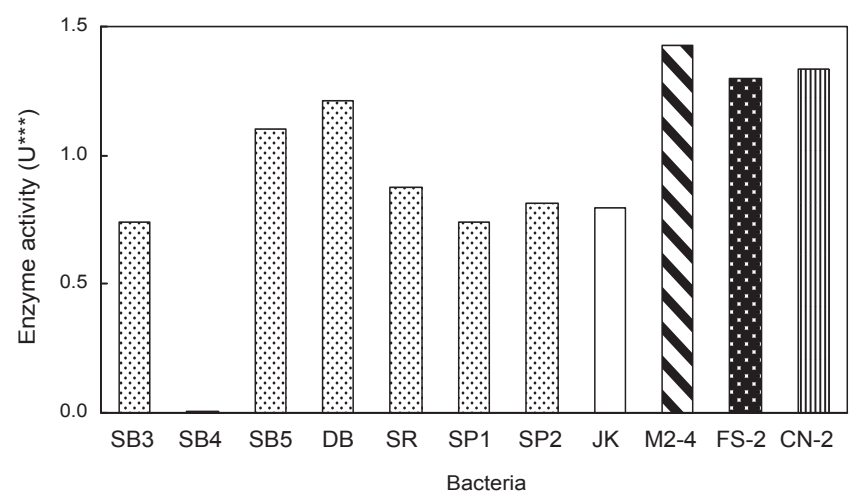

Fig. 4. Amidolytic activity of bacterial enzymes towards FALGPA.

Bacteria used in Fig. 4. are the same as in Fig. 2.

*** One unit $(U)$ of activity was defined as the decrease of 0.1 unit of absorbance at $324 \mathrm{~nm}$ in $24 \mathrm{~h}$ under assay conditions.

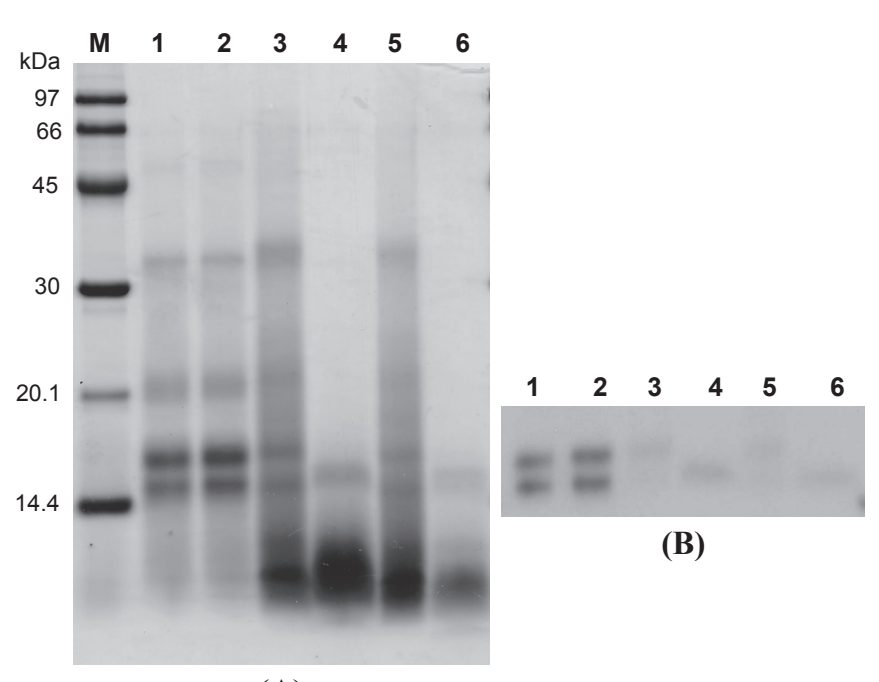

(A)

Fig. 5. SDS-PAGE (A) and immunoblot (B) of rice protein isolate fragments digested by B. subtilis DB and SR enzymes.

Lane $\mathrm{M}$, molecular weight marker; lane 1, rice protein isolates at $0 \mathrm{~h}$; lane 2, rice protein isolates at $24 \mathrm{~h}$; lanes 3-4, mixture of rice protein isolates and enzyme of $B$. subtilis $\mathrm{DB}$ at 0 and $24 \mathrm{~h}$, respectively; lanes 5-6, mixture of rice protein isolates and enzyme of $B$. subtilis $\mathrm{SR}$ at 0 and $24 \mathrm{~h}$, respectively.

to digest the main fragments of rice proteins with molecular masses of about 20 and $33 \mathrm{kDa}$. However, at before incubation, the low molecular mass protein fragments digested by these enzymes (lanes 3 and 5) were much more than those of controlled mixtures (lane 1), indicating that these enzymes had a high ability to digest rice proteins.

Rice proteins with molecular masses of about 14-16, 26,33 , and $56 \mathrm{kDa}$ were reported to be potentially reactive with IgE antibodies from patients with suspected rice allergy (Izumi et al., 1992). Figure 5B shows that controlled rice proteins cross-reacted with a monoclonal antibody within the molecular mass range of 14-16 kDa (lanes 1 and 2). The 0-h enzyme digested fragments (lanes 3 and 5) had cross-reactivity with a monoclonal antibody at a molecular mass of about $16 \mathrm{kDa}$. The 24-h enzymatic digested fragments (lanes 4 and 6) did not have cross-reactivity at $16 \mathrm{kDa}$, but were found to have cross-reactivity at $14 \mathrm{kDa}$.

The $16-\mathrm{kDa}$ allergenic rice protein was hydrolyzed by these two bacteria, so the allergenicity of rice protein was undetectable at this range. It was demonstrated, using immunoblotting, that these bacterial enzymes could reduce allergenicity of rice protein.

In addition, at the molecular mass of about $14 \mathrm{kDa}$, the 24-h digested fragments (lanes 4 and 6) had greater crossreactivity than that of the 0 -h digestion (lanes 3 and 5), indicating that digestion by these enzymes for $24 \mathrm{~h}$ could change the high molecular mass rice proteins into the $14-\mathrm{kDa}$ rice 
Table 2. Amino acid composition of rice proteins digested by isolated B. subtilis DB and SR ( $\mu \mathrm{g} / \mathrm{g})$.

\begin{tabular}{|c|c|c|c|}
\hline Amino acid & Controlled rice protein & Enzyme of B. subtilis DB & Enzyme of B. subtilis SR \\
\hline Aspartic acid & 0.64 & 31.46 & 81.91 \\
\hline Threonine & - & 725.20 & 622.21 \\
\hline Serine & 0.93 & 396.22 & 115.52 \\
\hline Glutamic acid & - & 440.89 & 2201.40 \\
\hline Proline & - & - & - \\
\hline Glycine & 1.95 & 452.81 & 439.70 \\
\hline Alanine & - & 2228.28 & 3452.93 \\
\hline Cysteine & - & - & - \\
\hline Valine & - & 8052.24 & 15341.37 \\
\hline Methionine & - & 1530.51 & 2920.06 \\
\hline Isoleucine & 4.27 & 3682.96 & 6459.26 \\
\hline Leucine & 2.02 & 7682.39 & 18176.48 \\
\hline Tyrosine & - & 2754.00 & 4104.57 \\
\hline Phenylalanine & - & 3258.66 & 5724.56 \\
\hline GABA & 179.27 & 1119.18 & 1357.26 \\
\hline Lysine & - & 1284.88 & 2525.12 \\
\hline Histidine & 0.58 & 754.97 & 818.36 \\
\hline Arginine & - & 1728.51 & 3614.85 \\
\hline Total & 189.66 & 36123.16 & 67955.56 \\
\hline
\end{tabular}

allergenic substances.

Table 2 shows the amino acid composition of rice proteins digested by $B$. subtilis DB and SR. Rice proteins digested by each enzyme released a high amount of several kinds of amino acids, especially valine and leucine, compared with the controlled rice proteins. This indicates that these bacteria could digest rice proteins into smaller units, i.e., amino acids. Moreover, almost all the amino acids released from digestion by $B$. subtilis SR were of larger quantity than those by $B$. subtilis DB. However, proline and cysteine were not found in the digested proteins. It may be concluded that these enzymes could not cleave rice protein at amino acid positions of proline and cysteine.

We previously found that aerobic bacteria, including Bacillus spp., naturally have the ability to produce large amounts of certain amino acids in fermented rice from Thai fermented rice-noodle processing (Kobayashi et al., 2007). These amino acids were glutamic acid, alanine, valine, leucine, phenylalanine, and $\gamma$-aminobutyric acid (GABA). The present study also found large amounts of the same kind of amino acids in digested rice proteins (Table 2). Additionally, microorganisms, including aerobic bacteria, lactic acid bacteria, fungi, and yeast, were present during the processing of Thai fermented rice-noodle (Kha Nhom Jeen) (Kobayashi et al., 2007). The amount of glutamic acid in fermented rice increased during the intermediate process that involved predominantly aerobic bacteria. Thereafter, the amount of GABA was also increased in the next process that was found to be predominant in lactic acid bacteria (Kobayashi et al., 2007). Therefore, we hypothesized that aerobic bacteria, such as Bacillus strains, digested rice proteins, leading to the increase in glutamic acid, with lactic acid bacteria subsequently producing GABA from this glutamic acid. The present study can be used as a basic experiment for utilizing isolated B. subtilis in the production of fermented rice products with high nutrient availability.

All isolated bacteria in this study were in the same species of B. subtilis, although they come from different food 
sources and locations. They showed enzyme activities towards synthetic substrates with various potentials, indicating each bacterium had specificity to each substrate even though they were of the same species. The use of B. subtilis in the food industry is recommended by the U.S. Food and Drug Administration as one of the GRAS (generally recognized as safe) microorganisms (Kramer and Gilbert, 1989; Denner and Gillanders, 1996). B. subtilis SR has the potential to reduce rice allergenicity and produce a large amount of glutamic acid from rice proteins, which is an important raw material for GABA production. It shows promise in its application for the production of hypoallergenic rice products, or use as a starter culture for improving the amount of GABA in the production of fermented rice products. Future study on the application of B. subtilis SR, together with lactic acid bacteria, in Thai fermented rice-noodle processing is needed to confirm and evaluate its capacity for producing nutrientrich fermented rice products, such rice-noodle.

Acknowledgements This work was supported, in part, by a Grantin-Aid (No.18300250 to H.N.) from the Ministry of Education, Culture, Sports, Science and Technology of Japan.

\section{References}

Ahn, M.Y., Hahn, B.S., Ryu, K.S., Kim, J.W., Kim, I. and Kim, Y.S. (2003). Purification and characterization of a serine protease with fibrinolytic activity from the dung beetle, Catharsius molossus. Thromb. Res., 112, 339-347.

Chantawannakul, P., Oncharoen, A., Klanbut, K., Chukeatirote, E. and Lumyong S. (2002). Characterization of proteases of Bacillus subtilis strain 38 isolated from traditionally fermented soybean in Northern Thailand. Sci. Asia, 28, 241-245.

Denner, W.H.B. and Gillanders, T.G.E. (1996). The legislative aspects of the industrial enzymes in the manufacture of food and food ingredients. In "Industrial Enzymology," ed. by T. Godfrey and S. West. The Macmillan Press Ltd., Basingstoke, pp 397-411.

Ikeda, M., Katoh, M., Nagano, H., Akuzawa, S., Izumi, H., and Omori, M. (2005). Allergenic protein in fermented rice noodles and the protease-producing bacterium. J. Home Econ. Jpn., 56, 417-424.

Inatsu, Y., Nakamura, N., Yuriko, Y., Fushimi, T., Watanasiritum, L., and Kawamoto, S. (2006). Characterization of Bacillus subtilis in Thua nao, a traditional fermented soybean food in northern Thailand. Lett. Appl. Microbiol., 43, 237-242.

Izumi, H., Adachi, T., Fujii, N., Matsuda, T., Nakamura, R., Tanaka, K., Urisu, A. and Kurosawa, Y. (1992). Nucleotide sequence of a cDNA clone encoding a major allergenic protein in rice seeds homology of the deduced amino acid sequence with members of $\alpha$-amylase/trypsin inhibitor family. FEBS Lett., 302, 213-216.

Jackson, R.J., Dao, M.L. and Lim, D.V. (1995). Modified FALGPA assay for cell-associated collagenolytic activity. J. Microbiol. Methods, 21, 209-215.

Kiers, J.L., Van Laeken, A.E., Rombouts, F.M. and Nout, M.J. (2000). In vitro digestibility of Bacillus fermented soya bean. Int. J. Food Microbiol., 60, 163-169.

Kimura, M. (1980). A simple method for estimating evolutionary rates of base substitutions through comparative studies of nucleotide sequences. J. Mol. Evol., 16, 111-120.

Kobayashi, A., Phromraksa, P., Katoh, M., Ikeda, M., Khamboonruang, C. and Nagano, H. (2007). Improvement of fermented rice noodles in Thailand and their characteristics. J. Home Econ. Jpn., 58, 463-470.

Kramer, J.M. and Gilbert, R.T. (1989). Bacillus cereus and other Bacillus species. In "Food-borne Bacterial Pathogens," ed M.P. Doyle. Marcel Dekker, New York, pp 21-70.

Laemmli, U.K. (1970). Cleavage of structural protein during the assembly the head of bacteriophage T4. Nature, 227, 680-685.

Leonel Ochoa-Solano, J. and Olmos-Soto, J. (2006). The functional property of Bacillus for shrimp feeds. Food Microbiol., 23, 519-525.

Li, G.H., Qu, M.R., Wan, J.Z. and You, J.M. (2007). Antihypertensive effect of rice protein hydrolysate with in vitro angiotensin I-converting enzyme inhibitory activity in spontaneously hypertensive rats. Asia Pac. J. Clin. Nutr., 16, 275-280.

Lima, C.A., Rodrigues, P.M.B., Porto, T.S., Viana, D.A., LimaFilho, J.L., Porto, A.L.F. and Carneiro da Cunha, M.G. (2009). Production of a collagenase from Candida albicans URM3622. Biochem. Eng. J., 43, 315-320.

Liu, C. and Nagano, H. (2008). Purification and Characterization of a proteolytic enzyme from Bacillus subtilis M2-4. J. Home Econ. Jpn., 59, 565-573.

Mills, E.N.C. and Breiteneder, H. (2005). Food allergy and its relevance to industrial food proteins. Biotechnol. Adv., 23, 409-414.

Nagano, H. and To, K.A. (2000). Purification of collagenase and specificity of its related enzyme from Bacillus subtilis FS-2. Biosci. Biotechnol. Biochem., 64, 181-183.

Ouoba, L.I., Diawara, B., Amoa-Awua, W., Traoré, A.S. and Møller, P.L. (2004). Genotyping of starter cultures of Bacillus subtilis and Bacillus pumilus for fermentation of African locust bean (Parkia biglobosa) to produce Soumbala. Int. J. Food Microbiol., 90, 197-205.

Ouoba, L.I., Thorsen, L. and Varnam, A.H. (2008). Enterotoxins and emetic toxins production by Bacillus cereus and other species of Bacillus isolated from Soumbala and Bikalga, African alkaline fermented food condiments. Int. J. Food Microbiol., 124, 224-230.

Peng, Y., Huang, Q., Zhang, R.H. and Zhang, Y.Z. (2003). Purification and characterization of a fibrinolytic enzyme produced by Bacillus amyloliquefaciens DC-4 screened from douchi, a traditional Chinese soybean food. Comp. Biochem. Physiol. B. Bio- 
chem. Mol. Biol., 134, 45-52.

Phromraksa, P., Nagano, H., Boonmars, T., and Kamboonruang, C. (2008). Identification of proteolytic bacteria from Thai traditional fermented foods and their allergenic reducing potentials. J. Food Sci., 73, M189-195.

Ravanti, L. and Kähäri, V.M. (2000). Matrix metalloproteinases in wound repair. Int. J. Mol. Med., 6, 391-407.

Saitou, N. and Nei, M. (1987). The neighbor-joining method: a new method for reconstructing phylogenetic trees. Mol. Biol. Evol., 4, 406-425.

Tamura, K., Dudley, J., Nei, M., and Kumar S. (2007). MEGA4: Molecular Evolutionary Genetics Analysis (MEGA) software version 4.0. Mol. Biol. Evol., 24, 1596-1599.

Tran, L.H. and Nagano, H. (2002). Isolation and characteristics of Bacillus subtilis $\mathrm{CN} 2$ and its collagenase production. J. Food
Sci., 67, 1184-1187.

Usui, Y., Nakase, M., Hotta, H., Urisu, A., Aoki, N., Kitajima, K. and Matsuda, T. (2001). A 33-kDa allergen from rice (Oryza sativa L. Japonica). cDNA cloning, expression, and identification as a novel glyoxalase I. J. Biol. Chem., 276, 11376-11381.

Van Wart, H.E, and Steinbrink, D.R. (1981). A continuous spectrophotometric assay for Clostridium histolyticum collagenase. Anal. Biochem., 113, 356-365.

Villadóniga, C., Battistoni, J. and Cantera, A.M.B. (2007). Monitoring immunoreactivity reduction of whey proteins hydrolysates by latex agglutination. Enzyme Microb. Technol., 40, 481-484.

Wang, C.T., Ji, B.P., Li, B., Nout, R., Li, P.L., Ji, H. and Chen, L.F. (2006). Purification and characterization of a fibrinolytic enzyme of Bacillus subtilis DC33, isolated from Chinese traditional Douchi. J. Ind. Microbiol. Biotechnol., 33, 750-758. 